\title{
Problems and Countermeasures of Internal Audit of Listed Companies in China
}

\section{Zhengni Ma*}

Zhejiang University of Finance and Economics, Hangzhou 310018, Zhejiang, China. E-mail: 670220376@qq.com

Abstract: As an important part of the management system of listed companies, the effective implementation of internal audit can improve the comprehensive level of enterprises and promote the long-term and stable development of enterprises. Since the reform and opening up, China's internal audit in the exploration of continuous progress, gradually standardized, systematic. However, due to historical and realistic reasons, the internal audit independence of listed companies in China is poor, the overall quality of internal audit personnel is not high, the field and scope of internal audit is narrow, it is difficult to effectively deal with the complex and changing market environment, enterprises face financial, operational and other risks. Therefore, the internal audit of listed companies needs to be transformed and upgraded. This paper introduces the current situation of internal audit of listed companies in China, further analyzes their existing problems, and puts forward solutions to these problems.

Keywords: Listed Companies; Internal Audit; Problems; Countermeasures

\section{The current situation of internal audit of listed companies in China}

In 1983, China's modern sense of internal audit began to start. In 2008, the Basic Norms of Internal Control of Enterprises requires that all listed companies must set up internal audit departments, deploy professional internal audit personnel, and improve the supervision mechanism of internal audit of enterprises. The internal audit system is gradually standardized and systematic. Compared with the West, the construction of internal audit in China started late, although great improvement has been made, there are still a series of problems. In recent years, China's listed companies audit failure cases, such as: Bluefield shares, Wanfu Biotechnology and other companies involved in financial fraud, internal audit has not played a substantial role in supervision, or even existed in name only. The importance of internal audit to listed companies is not fully recognized, and its management role is not well played. At the first meeting of the Central Audit Committee, General Secretary Xi Jinping stressed the need to strengthen the guidance and supervision of internal audit work and mobilize the power of internal audit. The new era has given a new mission to China's internal audit, and the internal audit of china's listed companies has ushered in an unprecedented period of development opportunities.

\section{Problems in internal audit of listed companies}

Due to the late start of internal audit in China, a law specifically for internal audit has not yet been formed. Although all listed companies are required to set up internal audit departments, the company owners pay less attention to internal audit, there are some problems in the independence, team building and field scope of internal audit of listed companies.

\subsection{Poor independence of internal audit}

The Company Law stipulates that the internal audit department of listed companies belongs to the board of directors or the audit committee under it, and at this stage such kind of audit institution setup model has been established 
in china's listed companies, but it has not fully played the role of supervision of the internal audit institutions. At present, the equity structure of listed companies in China is unreasonable, the phenomenon of equity in the hands of a few people is widespread, easy to appear internal control phenomenon, weaken the rights of internal audit institutions. Most audit committees are set up under the Board of Directors and follow the arrangements of superiors, as a matter of fact, their establishment is mostly a mere formality and does not have a substantial effect. Therefore, the independence of internal audit cannot be guaranteed, the real situation of enterprises cannot be objectively and fairly reflected.

\subsection{The overall quality of internal audit personnel is not high}

The comprehensive quality of internal auditors is mainly reflected in two aspects: professional ability and professional ethics. In terms of professional ability, due to the low degree of attention paid to internal audit by listed companies in China, the internal audit personnel are mostly held concurrently by the personnel of the financial department, and lack professional audit skills and professional theoretical knowledge. Internal audit personnel's academic qualifications are also uneven. In recent years, the academic level of the internal audit team has been greatly improved compared with the past. Nevertheless, undergraduate and above education personnel still account for a minority. The complexity of the audit requires more operational capacity for auditors and the development of the situation requires internal auditors to have modern audit concepts and digital thinking. In terms of professional ethics, some internal auditors lack basic professional ethics, turn a blind eye to corporate fraud, and even under the interests of the right to seek personal gain, resulting in the listed company fraud cases emerge endlessly, seriously affecting the social and economic order.

\subsection{Narrow field and scope of internal audit}

Compared with international internal audit, the field and scope of domestic internal audit are narrow. And still stay in the financial accounting level of the audit, mainly review accounting vouchers, accounting books, accounting statements, etc. Check the authenticity and completeness of this information, the field of enterprise management is not in-depth. The purpose of internal audit is to serve the enterprise management, the scope of audit must involve all aspects of the enterprise. In the current economic situation, the market competition is increasing, the narrow scope of internal audit cannot improve the comprehensive level of enterprises, also cannot guarantee its long-term stable development. In addition, the internal audit of china's listed companies often pay attention to the concurrent audit and post audit, ignoring the pre-audit. We fall short in analysis of potential risks, forecasting business prospects, and finding weaknesses in internal control so that we are unable to address issues affecting the company's development in the bud.

\section{Countermeasures to existing problems in internal audit}

The existing problems of the above-mentioned internal audit have a great impact on china's listed companies, we must pay attention to them. A number of countermeasures are put forward in this paper, hope to help perfect the internal audit system of China's listed companies and improve the quality of internal audit.

\subsection{Increased independence of internal audit departments}

In order to improve the independence of internal audit department, listed companies first need to attach importance to internal audit, enterprise leaders, especially the leadership of the highest decision-making level to change the understanding of internal audit, will have a great impetus to the internal audit work. In contrast, the audit committees set up by listed companies in the United States are composed of independent directors who are not involved in the day-today operations of the company, providing a better environment for internal audit work. Therefore, we should increase the proportion of independent directors in the internal audit institutions, actively explore the model of internal audit institutions suitable for listed companies, determine the division of power and responsibilities among the internal audit department, the supervisory board and the audit committee. Ensure the internal audit department's oversight of decisionmaking, management and executive levels through the mutual restriction of rights between the supervisory board and the board of directors. In order to ensure that the internal audit department plays its supervisory role and guarantees the independence of internal audit.

\subsection{Strengthen the construction of the internal audit team}


Strengthening the construction of the internal audit team mainly includes improving the internal audit personnel's professional ability and professional ethics. In the first instance, internal auditors must have a good professional ethics, which should be the minimum standard for listed companies to select internal auditors. Secondly, because of the complexity of audit work, auditors are required to have systematic and professional knowledge, with rich audit experience, audit skills and independent judgment. With the continuous development of Internet, big data, Internet of Things, cloud computing, artificial intelligence and other technologies, the security threat of enterprise information system will become more and more serious, internal audit also needs to speed up the construction of information technology. Consequently, internal auditors should also master computer audit and other advanced audit technology. Listed companies ought to establish an internal audit talent pool and then take the above aspects into account when selecting personnel. In the meantime, strengthen the training and assessment of internal auditors, so that they constantly update their professional knowledge, and gradually improve the overall quality and professional judgment. In addition, enterprises also need to optimize the structure of internal audit departments, bring in experts from other fields, such as: legal experts, economic experts, etc. Set up a comprehensive, high-quality composite internal audit talent pool.

\subsection{Broaden the field and scope of auditing}

The field of internal audit abroad is very extensive and the content is quite in-depth, which has already been involved in enterprise development strategy and business decision-making audit, auditing of R\&D expenses, human resources management audit. Social responsibility audit, "green" audit also has been included in the scope of internal audit. Since the 21 st century, although our country has learned from foreign experience, expanded the scope of audit from financial audit to management benefit audit, the realization of management benefit audit still has a long way to go. As a new requirement for internal audit in the new era, enterprise development planning audit has been paid more and more attention by enterprises. As far as the current situation is concerned, the competition among enterprises intensifies, and the risks of internal business are constantly emerging. If china's listed companies want to achieve the goal of valueadded services for enterprises through internal audit, they must continue to expand the field and scope of internal audit. The transition from operational audit to development planning audit is an important trend in the development of internal audit.

\section{Summary}

The internal audit work is of great significance to the stable operation of listed companies. Thus enterprises ought to improve the proportion of independent directors in the internal audit institutions and guarantee the independence of the internal audit department; Strengthen the construction of the internal audit team, improve the comprehensive quality of internal audit personnel, establish a comprehensive, high-quality composite internal audit talent pool; Broaden the field and scope of audit, conform to the requirements of the new era, convert from operational audit into development planning audit. Eventually, improve the internal audit system as well as the comprehensive level of enterprises, promote the long-term and stable development of enterprises as well.

\section{References}

1. Ma H. Research on the independence of internal audit of listed companies (in Chinese). Modern Economic Information 2019; (18): 208.

2. Wang Y. Discussion on internal audit of listed companies in China (in Chinese). Journal of Dongbei University of Finance and Economics 2014; (4): 33-36.

3. Qin R. New mission and new path of internal audit in China (in Chinese). Friends of Accounting 2019; (8): 2-5.

4. $\mathrm{Xu}$ Y. Retrospect and prospect of the changes of China's internal audit system in the past 40 years (in Chinese). Internal Auditing in China 2019; (2): 34-39.

5. Lin H. A probe into the construction and management of internal audit talents in enterprises (in Chinese). Finance \& Accounting for Communications 2019; (11): 79-83.

6. Duan K, Enron. Research on internal audit of listed companies (in Chinese). Economic Research Guide 2018; (27): $116+127$. 
7. Yang $X$. The defects and improvements of the internal audit law system of Chinese enterprises (in Chinese). Marketing Research 2017; (1): 52-54. doi: 10.13999/j.cnki.scyj.2017.01.022.

8. Chen Z. Discussion on the setting up of internal audit institutions of listed companies in China (in Chinese). Jiangxi University of Finance and Economics; 2014.

9. Bi X, Chen S. Construction of "Audit Intelligence" in the era of new technology (in Chinese). Auditing Research 2019; (6): 13-21.

10. Research on the internal audit information system of enterprises under the integration of industry and finance (in Chinese). Friends of Accounting 2019; (21): 25-28. 